„Dziś piękność Twą w całej ozdobie widzę i opisuję, bo tęsknię po Tobie..."

\title{
WSPOMNIENIA KAPELANA
}

Historia Polski, pokiereszowana jak oblicze Pani Jasnogórskiej, nie wiele dała narodowi naszemu możliwości do radości - aż oto w dniu 16. X. 1978, w dzień św. Jadwigi Sląskiej, nastąpiła eksplozja radości - euforia ogarnęła naszą Ojczyznę, bo na stolicy Piotrowej zasiadł Polak, syn ziemi krakowskiej, Arcypasterz wawelskiego grodu, Karol kardynał Wojtyła.

"Sprawił to Pan i dziwne jest to w naszych oczach..."

Zaśpiewała Polska dziękczynne Magnificat, gdyż Pan uczynił jej wielkie rzeczy - zaśpiewał Kościół Chrystusowy potężne Te Deum za to, że otrzymał w darze od Ducha Swiętego gorliwego Pasterza dusz, tytana pracy, czlowieka o maksymalnych walorach umysłu, woli i serca.

O Janie Pawle II zaraz po jego wyborze na papieża środki masowego przekazu wyrażały się w superlatywach i czynią to dotąd. Podkreślają jego dar komunikatywności, jego zawsze pogodne, fascynujące oblicze, emanującą zeń dobroć, życzliwość, uśmiech dla wszystkich, jego umiłowanie dzieci i młodzieży, jego czułe serce dla chorych, kalek, osób samotnych, jego zaangażowanie w sprawy trzeciego świata, jego ducha mediacji, jego bezkompromisowe wystąpienia odnośnie wolności religijnej, społecznej itd.

$\mathrm{Z}$ bardzo bogatego wachlarza jego duszpasterskiej działalności na stolicy św. Stanisława, Bpa i Męczennika w Krakowie, będę usiłował nakreślić kilka znamiennych wycinków, a to: praca nad młodzieżą, wizytacje kanoniczne i apostolstwo chorych, jak i osób samotnych.

Młodzieży poświęcał się od zarania swego kapłaństwa, uwielokrotnił to poświęcenie jako Biskup. Akademicka młodzież miała w nim zawsze swego mecenasa, swego niezastąpionego Protektora. Nie szczędził nigdy czasu na spotkania w akademickich zespołach - przy kolegiacie św. Anny, u Księży Jezuitów na Wesołej, u Ojców Dominikanów czy u Księży Misjonarzy na Nowej Wsi. W czasie adwentowym dzielił się w kościołach akademickich $\mathrm{z}$ akademicką bracią opłatkiem; po Bożym Narodzeniu urządzał 
w swej rezydencji występy kolędowe, a w gorących dniach egzaminów modlił się razem $z$ nimi o dobre wyniki egzaminów.

Ale nie tylko młodzieżą, akademicką czy szkół średnich zajmował się On nieustannie, bo leżała mu na sercu bardzo młodzież pracująca - wszak sam jako młody człowiek, za okupacji, zaznał doli robotnika w kamieniolomach czy w fabryce „Solvay" - i dlatego problemy świata pracy nie były mu obce, owszem umiał je znakomicie rozwiązywać. „Oczkiem w głowie” była dla Niego młodzież klerycka, odwiedzał ją, a wiadomo, jak na duchu podnosiły Seminarzystów takie arcypasterskie odwiedziny.

Drugi dział Jego posługiwania duszpasterskiego to wizytacje kanoniczne. Już jako biskup pomocniczy wprowadził nowy styl wizytacji kanonicznej, a kiedy został ordynariuszem, zwykł był mawiać: „Jako ojciec diecezji chcę znać wszystkie parafie, dlatego staram się je sam nawiedzać; na wizytacji bowiem docieram bezpośrednio do wszystkich mych diecezjan".

Każdą wizytację rozpoczynał od udzielania bierzmowania, sakramentu umocnienia poprzedzonego colloquium z mającymi przystąpić do tego Sakramentu. Obrzęd sakramentalny kończył zawsze mocną adhortacją, by bierzmowani znaczyli swe życie dobrymi uczynkami płynącymi z wiary, umocnionej tym sakramentem Ducha Swiętego.

Novum, jakie wprowadził na wizytacjach, było błogosławienie każdej z osobna pary małżeńskiej. Błogosławił je po odprawieniu Mszy św. i nauce stanowej dla małżonków. Z autopsji mogę powiedzieć, że to arcypasterskie błogosławieństwo poruszało do łez, i to nierzadko, pary małżeńskie.

Wizytacja byla spotkaniem ze wszystkimi parafianami z młodzieżą, małżonkami, dziećmi, osobami starszymi i samotnymi, z chorymi i maluchami, którym poświęcał ostatnie godziny wizytacyjne i które błogosławił, kropił wodą święconą na pamiątkę chrztu świętego i z którymi wspólnie się modlił. Ten ostatni akt wizytacyjny był jakby żywcem wyjęty z Ewangelii, był jakby odbiciem tej sceny (zanotowanej przez synoptypków - Mt 19, 13-14; Mk 10, 13-14; Łk 18, 15-16), kiedy to Chrystus przygarniał do siebie dzieci, obejmował je, kładł na nie ręce i blogosławił je i mówił: „takich jest Królestwo niebieskie...”

Trzecią umilowaną dziedziną pracy Metropolity krakowskiego było apostolstwo chorych i osób samotnych. Poświęcał się dla nich bez reszty. Nie przerażała go jazda furmanką po kamienistej i wyboistej drodze w Zawoi, by dotrzeć do młodego człowieka ze złamanym kręgosłupem i udzielić mu w domu Sakramentu bierzmowania. Nie męczyło go nigdy odwiedzanie chorych po szpitalach 
czy - w czasie wizytacji - po domach. Ze wzruszeniem wspominam tę chwilę, kiedy na kilka dni przed śmiercią odwiedzić raczył moją matkę, pocieszał ją, udzielił jej błogosławieństwa. Był to prawdziwie kojący balsam dla ciężko chorej mej matki. A - trzeba to podkreślić - nigdy nie brakło Arcypasterza u chorych kapłanów. Odwiedzał ich nie tylko w Krakowie, ale i poza jego granicami. W ogóle chorzy i cierpiący byli dla niego uprzywilejowaną cząstką jego owczarni...

Jak oceniali chorzy i osoby samotne spotkania z Arcybiskupem - niech to potwierdzą dwie wypowiedzi; jedna od chorej, druga od samotnej osoby.

„Przeżyłam te odwiedziny jako ogromną radość, którą do dziś odczuwam, jako jasność wewnętrzną. Człowiek chory, przez swe dolegliwości, przez odosobnienie i zamknięcie w czterech ścianach, czuje się odizolowany od spoleczeństwa, zapomniany i smutny. I to poczucie znikło, jak znika ciemność z nastaniem poranka. Poczułam się znowu ,kimś" - przestało mnie dręczyć poczucie niepotrzebności, bo doznałam tak namacalnie, po ludzku, Bożą Opatrzność, bo przecież pamięta o mnie Kościół, i to w osobie przedstawiciela hierarchii. Tak bardzo wówczas przeżyłam jedność w Kościele" (z wizytacji w Chrzanowie).

Bardzo inteligentna osoba pisze: „Nie ma człowieka samotnego, jeśli się sam na samotność nie skaże - mówił kardynał - jeśli się sam na samotność nie skaże przez zamknięcie się w sobie, przez niedostrzeganie obok siebie człowieka czekającego na jego słowa, ręce, modlitwę! Pojąłem głębokość tych słów i zacząłem się serdecznie modlić, aby mi Bóg pozwolił wprowadzić te słowa w czyn, abym umiał zapomnieć o sobie i bym był otwarty dla innych, tak jak Sobór Watykański drugi otwarł serce Kościoła dla wszystkich potrzebujących. Modlić się będę, aby błogosławieństwo Arcypasterza, którego nam, osobom samotnym, udzielił, pomogło mi na co dzień w wyrwaniu się z poczucia samotności przez posługę innym. Błogosławię Bogu, że w dniach wizytacji kanonicznej doświadczyłem i przekonałem się, jak wygląda Ewangelia na co dzień, jak ją wciela w życie Arcypasterz..."

Dobry Bóg pozwolił mi osobiście uczestniczyć w uroczystościach intronizacji Ojca świętego, Jana Pawła II. Żyję dotąd wspomnieniami tych podniosłych chwil. Dotąd brzmią mi w uszach jego słowa skierowane do Polaków: „Cóż mam powiedzieć do Was? co powiedzieć? Wszystko, co mógłbym powiedzieć będzie blade w stosunku do tego, co czuje w tej chwili moje serce i wasze... Niech pozostanie tylko wielkie milczenie przed Bogiem, które jest samą modlitwą!"

Te ostatnie słowa odsłoniły nam Jana Pawła II jako męża modlitwy, żarliwej modlitwy, żyjącego w ciągłym kontakcie z Bogiem. Kontakt ten umacnia codziennym sprawowaniem Mszy świę- 
tej, z której czerpie wzór i nadziemską siłę, a którą celebruje z najwyższą religijną czcią, ze skupieniem i pobożnością, głęboko wierząc, że ,składa Ojcu Prżedwiecznemu tę samą ofiarę Syna Bożego, co na Golgocie... ofiarę, która jest rzeczywistością nadprzyrodzoną, niezgłębioną, do głębi boską i równocześnie do głębi ludzką, w której człowiek i Bóg, Bóg i człowiek spotykają się przez miłość, a w której Syn Boży przystępuje zawsze do Ojca $z$ całokształtem spraw ludzkich. Jest przecież naszym Odkupicielem..." (kazanie 3. 7. 63 na Wawelu w 30 dniu od śmierci Jana XXIII).

Tak ceni Mszę św., że nawet w dniach niemocy i dokuczliwej choroby dźwiga się i z trudem ją odprawia. To co akta kanonizacyjne mówią o św. Janie Vianneyu: „Był wprost rozrywany najrozmaitszymi zajęciami, a mimo to nieustannie rozmawiał z Bogiem" - śmiało można zastosować do Jana Pawła II. Ma swoje ulubione nabożeństwo, a więc: Drogę krzyżową (odprawia ją zazwyczaj we wtorki i piątki każdego tygodnia), Dróżki kalwaryjskie, którymi kroczył kilkakroć w roku, ale jak kapłan maryjny (hasło znane: Totus Tuus) przynależność swą do Niepokalanej podkreśla umiłowaniem szkaplerza świętego (nosi go z pietyzmem, ten znak przymierza, opieki i zbawienia), a już najbardziej umiłowaniem Różańca świętego, z którym niemal się nie rozstaje, czego dowodem fotografie, choćby tylko te $z$ pierwszych dni jego pontyfikatu, kiedy to wiwatującym rzeszom odpowiada gestem podniesionych rąk, w lewej ściskając różaniec. Na temat różańca wypowiadał się bardzo często przy różnych okazjach, a w rekolekcjach watykańskich, głoszonych na zaproszenie Pawła VI w 1976 r. aż trzy konferencje poświęcił rozważaniu tajemnic różańcowych.

W kulcie Swiętych Pańskich na pierwsze miejsce wysuwa się u Jana Pawła II (tak mi się zdaje) św. Józef. Jako Arcypasterz Krakowa często wczesnym rankiem udawał się do kościoła Sióstr Bernardynek, gdzie patronuje w łaskami słynącym obrazie św. Oblubieniec Bogarodzicy, i tam u stóp Troskliwego Obrońcy Chrystusa składał swe duszpasterskie troski. W gorliwości i poświęcaniu się bez reszty duszom jest wiernym naśladowcą swego Patrona, św. Karola Boromeusza. Naśladuje swego Patrona również i w urządzaniu zebrań, sympozjów, w których biorą udział uczeni duchowni i świeccy. Za czasów św. Karola zebrania takie nosiły nazwę: „Noce watykańskie”. Patron archidiecezji krakowskiej, św. Stanisław biskup jest dla niego wzorem „Dobrego $\mathrm{Pa}$ sterza" w nieugiętej postawie, gdy „wczas, nie wczas" (2 Tm 4, 2) ostrzega przed złem, wciskającym się w różnych formach do nieśmiertelnych dusz, drogami niewiary i niemoralności. Dawał tego dowody w kazaniach na Boże Ciało w Krakowie czy na pielgrzymce mężów w Piekarach \$1. Takim kardynała Wojtyłę mężem 
modlitwy widziała go krakowska archidiecezja, takim go widzi dziś cały Kościół, jako papieża. Ceni modlitwę, prosi o nią. W spotkaniu z Polakami po intronizacji wołał: „Nie zapominajcie o mnie w modlitwie na Jasnej Górze i w całej naszej Ojczyźnie...”.

W parze $z$ modlitwą idzie u Jana Pawła II życie pełne abnegacji. Nigdy go nie słyszano skarżącego się albo narzekającego na jakieś dolegliwości, a przecież dokuczały mu częste bóle głowy (pozostałość po okupacji) i kamienie nerkowe, i korzonki itd. modlił się tylko jak dziecko: „Panie, Boże mój, jam robaczek Twój...". Wstrzemięźliwość w pokarmach była osobliwa. Gdy raz ośmieliłem się zauważyć: „Eminencja nie powinien w umartwieniach naśladować św. Jana Vianney, bo św. Proboszcz z Ars miał inny wymiar pracy" - skwitowal moją uwagę rozbrajającym uśmiechem. (Już to, że pozwolił sobie zwrócić uwagę, dowodzi jego pokory)!

Jan Paweł II to następnie mąż twórczego czynu. On wprawdzie „uderza w czynów stal” (Psalm Nadziei) On „mnoży się przez czyny żyjące... i w ciągłej przykładu i słowa postaci, rozdaje siebie samego swej braci" (Ressurrecturis) nikomu nie odmawiając swej posługi, idąc $\mathrm{w}$ tym za przykładem św. Jana z Kęt... $(O$, qui negasti nemini opem roganti). U Jana Pawła czyny poprzedzają słowa, jak u Chrystusa, który „czynił i nauczał” (Dz 1, 1).

Dzięki jego inicjatywie, gdy był jeszcze metropolitą krakowskim powstała akcja na rzecz małżeństw i rodzin, akcja charytatywna na rzecz chorych, kalek i osób samotnych, urządzał dla nich rekolekcje zamknięte (Trzebinia, Kalwaria), „wczasy” dla wyżej wymienionych (Międzybrodzie - Dursztyn) itp. Mężem twórczego czynu okazał się w kontaktach międzynarodowych - czy to, gdy wyruszał na różne kontynenty $\mathrm{z}$ wieloraka posługą (USA - Kanada - Australia, a w Europie RFN i NRD), czy wówczas, gdy pracował intensywnie na Vaticanum II czy na Synodzie Biskupów.

Horoskop Jego pontyfikatu ujął proroczo Juliusz Słowacki:

„Wszelką z ran świata wyrzuci zgniłość,

Robactwo - gad,

Zdrowie przyniesie - rozpali miłość

Podźwignie świat..."

A trzeba mocy, byśmy ten Pański

Dźwignęli świat:

Więc oto idzie papież słowiański,

Ludowy brat...

Powiedział Jan Paweł II o Mszy świętej, że Jezus wyszedł, żeby szukać każdego człowieka i dlatego we Mszy św. jest wołanie o każdego człowieka. On Jan Paweł II, na wzór swego Mistrza 
i Pana, szuka go we wszystkich narodach, na całym globie ziemskim (Meksyk 1979), chce dowartościować upośledzone społeczeństwa, a próbkę tego dowartościowania dał w dniu swej intronizacji, gdy na oczach całego świata przemówił, jak nigdy dotąd żaden $z$ papieży - słowiańskimi językami...

Niech tych kilka słów będzie wyrazem szczerego homagium od oddanego $\mathrm{Mu}$ sercem kapelana...

Ks. JÓZEF DOWSILAS 